\title{
EFFICACY OF ESSENTIAL OILS IN THE MANAGEMENT OF SOFT ROT CAUSED BY Pectobacterium aroidearum IN LETTUCE
}

\author{
Karol Alves BARROSO ${ }^{1}$ (iD) Xênia Bastos de OLIVEIRA² (iD), Márcia Ferreira QUEIROZ $^{3}$ (D), \\ Camila de Oliveira ALMEIDA ${ }^{4}$ (D), Vitor Prates LORENZO ${ }^{5}$ (D), Flávia Cartaxo Ramalho VILAR ${ }^{5}$ (i), \\ Cristiane Domingos da PAZ ${ }^{6}$ iD, Ana Rosa PEIXOTO ${ }^{6}$ (iD)
}

\footnotetext{
${ }^{1}$ Postgraduate Program in Phytotechnics, Federal Rural University of the Semi-Arid, Mossoró, Rio Grande do Norte, Brazil.

${ }^{2}$ Postgraduate Program in Agronomy: Irrigated Horticulture, State University of Bahia, Juazeiro, Bahia, Brazil.

${ }^{3}$ Postgraduate Program in Phytopathology, Federal University of Viçosa, Viçosa, Minas Gerais, Brazil.

${ }^{4}$ Graduate in Agronomy, State University of Bahia, Juazeiro, Bahia, Brazil.

${ }^{5}$ Department of Teaching, Federal Institute of Education, Science and Technology of Sertão Pernambucano, Petrolina, Pernambuco, Brazil.

${ }^{6}$ Department of Technology and Social Sciences, State University of Bahia, Juazeiro, Bahia, Brazil.
}

\section{Corresponding author:}

Karol Alves Barroso

Email: k.alvesbarroso@gmail.com

How to cite: BARROSO, K.A., et al. Efficacy of essential oils in the management of soft rot caused by Pectobacterium aroidearum in lettuce. Bioscience Journal. 2021, 37, e37095. https://doi.org/10.14393/BJ-v37n0a2021-54179

\begin{abstract}
Lettuce is susceptible to several diseases, especially soft rot caused by bacteria of the genus Pectobacterium. Due to the adaptability of this pathogen and the lack of disease control registered for the crop, the objective of this work was to evaluate the effects of essential oils in the management of soft rot caused by $P$. aroidearum in lettuce. The study was developed at the Universidade do Estado da Bahia, Juazeiro, BA, Brazil, and the essential oils (EOs) of orange, bergamot, lemongrass, palmarosa, citronella, cloves, tea tree, rosemary, sage, and ginger were used in concentrations of $0.25 ; 0.5 ; 0.75$ and $1.0 \%$ to assess the in vitro growth inhibition of the bacterium. Subsequently, the curative effects of the disease were evaluated by applying the EOs that obtained the best results in vitro in lettuce plants of the susceptible variety "Mônica". The treatments were applied, via spraying, 12 hours after inoculation using the bite method with bacterial suspension. The best in vivo treatment was selected to assess its preventive and curative activity, as well as to find the ideal concentration for reducing epidemiological variables and chromatographic characterization. The EOs of palmarosa, sage, citronella, lemongrass, and cloves $(0.25 \%)$, and that of sage (0.75\%), inhibited bacterial growth in vitro. The EO of salvia showed the best results in vivo, inhibiting the growth of the disease in concentrations of 0.50 and $0.75 \%$, so it was selected for the preventive and curative control tests alone. The preventive treatment was not efficient for the management of soft rot in lettuce, however, from the regression analysis, a concentration of $0.64 \%$ of the salvia EO was found as a potential for curative control of this bacteriosis, as it reduces the incidence and severity of the disease. Linalyl acetate and linalool were found in higher concentrations in the chromatographic analysis. These components, probably, conferred the bactericidal capacity of the EO of sage, being potential for the use in the control of $P$. aroidearum in lettuce.
\end{abstract}

Keywords: Alternative control. Curative control. Essential oil of sage. Lactuca sativa. Preventive control.

\section{Introduction}

Lettuce (Lactuca sativa L.) is the most produced and consumed leafy vegetable (Sediyama et al. 2016). It has also great economic, nutritional, and social importance, as it is primarily grown by family farmers (Sala and Costa 2012). However, this crop is subject to factors that might limit its production and 
depreciate product quality for marketing and consumption. Bacterial diseases are one of the most limiting factors of lettuce crops, primarily those caused by the genus Pectobacterium, which causes soft rot (Beriam 2007). These bacteria are characterized by penetrating plant tissue through natural or mechanical injuries, the ability to survive in the soil, mainly with high humidity and to be disseminated via seeds (Michereff et al. 2005).

Recently, the species Pectobacterium aroidearum has been described as a highly virulent species, mainly in monocotyledons (Nabhan et al. 2013), and in Brazil was reported by Barroso et al. (2019) causing symptoms of soft rot in lettuce. The initial symptom of this disease in lettuce is the appearance of wilt in outer leaves, caused by the collapse of vascular tissues. As the disease progresses, the stem might show maceration, and the plant will rot. This disease can occur both in the pre- and post-harvest (Raid 1997).

Due to the high adaptability of this pathogen and the lack of registered control for Pectobacterium in the lettuce, it is necessary to search for alternatives for the effective phytosanitary management of this crop. In this regard, the use of essential plant oils stands out. Essential oils can be defined as aromatic and volatile products derived from secondary plant metabolism, found in leaves, flowers, fruits, and skins of several plant species (Conner 1993; Silveira et al. 2012).

Several substances with antibiotic potential are found in the chemical composition of these natural products, which ought to be studied either for their direct use by rural farmers or as raw material for the formulation of new products. However, their antimicrobial activity might vary depending on the geographical location of the plant material, harvest season, genotype, and climatic conditions. Therefore, it is important to characterize the chemical composition and biological activity of essential oils obtained from plants of a given region (Viuda-Martos et al. 2010; Militello et al. 2011).

Considering the wide antimicrobial potential of essential oils, the aim of this study was to evaluate the effect of different essential oil concentrations in the management of soft rot in lettuce caused by Pectobacterium aroidearum.

\section{Material and Methods}

This study was conducted at the Phytopathology Laboratory and greenhouse of the Department of Technology and Social Sciences (DTCS) of the State University of Bahia-UNEB, Campus III, Juazeiro-BA, Brazil.

\section{Obtaining and preparing the inoculate}

The isolate Pectobacterium aroidearum (UNEB 3) was obtained from lettuce of the 'Elba' variety with symptoms of soft rot in a vegetable garden in the municipality of Petrolina-PE, Brazil $\left(9^{\circ} 21^{\prime} 39,8^{\prime \prime} \mathrm{S}\right.$; $40^{\circ} 32^{\prime} 27,2^{\prime \prime} \mathrm{O}$ ). It was then preserved in sterile distilled water (SDW) in the collection of the Phytopathology Laboratory of the State University of Bahia (UNEB).

An isolate pathogenicity test was performed with lettuce seedlings, clipped lettuce leaves, and clipped chard leaves (Beta vulgaris L.), using the method of injecting a bacteriological suspension of the isolate, adjusted in $A_{530}=0.36\left(1 \times 10^{9} \mathrm{UFC} \cdot \mathrm{mL}^{-1}\right)$, with $48 \mathrm{~h}$ of incubation (Mariano and Souza 2016). Once the typical symptoms of soft rot caused by Pectobacterium aroidearum appeared, reisolation was performed to prove Koch's assumptions.

\section{Essential oils}

We used ten $100 \%$ pure and natural vegetable oils of medicinal and aromatic plants from Phytoterapica - Solua Comercial Ltda in the present study; clove (Eugenia caryophyllata Thunb), citronella (Cymbopogon winterianus Jowitt), bergamot (Citrus bergamia Risso et Poiteau), Rosemary (Rosmarinus officinalis L.), palmarosa (Cymbopogon martin [Roxb.] Wats), sage (Salvia sclarea L.), ginger (Zingiber officinale Roscoe), melaleuca (Melaleuca alternifolia Maiden \& Betche, Cheel), orange (Citrus aurantium L.), and lemongrass (Cymbopogon citratus Stapf). 


\section{In vitro sensitivity of Pectobacterium aroidearum to essential oils}

For the in vitro study, essential oils were added to the CPG medium ( $1 \mathrm{~g}$ of hydrolyzed casein, $10 \mathrm{~g}$ of peptone, $10 \mathrm{~g}$ of glucose, $18 \mathrm{~g}$ of agar, and $1000 \mathrm{~mL}$ of distilled water) for the following treatments: essential oils at $0.25 \%, 0.5 \%, 0.75 \%$, and $1.0 \%(\mathrm{v} / \mathrm{v})$ concentrations, and at $0 \%$, which consisted of the witness. The culture medium mixed with each oil (and its respective concentration) was added to Petri dishes with $9 \mathrm{~cm}$ diameter and kept under refrigeration at approximately $12^{\circ} \mathrm{C}$ for 48 hours.

After this period, the bacterial suspension of the isolate Pectobacterium aroidearum (UNEB 3) was prepared, obtained from fresh cultures in CPG medium incubated for 48 hours at $28^{\circ} \mathrm{C}$. The bacterial suspension concentration was adjusted in $A_{530}=0.36\left(1 \times 10^{9} \mathrm{UFC} \mathrm{mL}^{-1}\right)$ with the help of a photocolorimeter (Analyser 500, Brazil). After that, $100 \mu \mathrm{L}$ of bacterial suspension $P$. aroideraum, previously diluted in ADE until $10^{-6} \mathrm{UFC} \mathrm{mL}^{-1}$, was spread over the CPG medium with a Drigalski strap. Petri dishes were incubated at $28^{\circ} \mathrm{C}$ for $48 \mathrm{~h}$ in a BOD (Biochemical Oxygen Demand) type incubator.

In vitro sensitivity of the $P$. aroidearum isolate to essential oils was determined by counting colonies per dish and by calculating UFC/mL, according to the methodology by Paret et al. (2010).

\section{Essential oils in the control of soft rot in lettuce}

Lettuce seedlings from the susceptible variety 'Mônica' were used to evaluate the direct effect of essential oils in the control of soft rot caused by $P$. aroidearum. Sowing was performed into plastic trays containing a commercial substrate, and after 18 days, seedlings were transplanted to $500-\mathrm{mL}$ vases containing commercial substrate and sand at a 2:1 (v/v) ratio, previously sterilized in an autoclave for $2 \mathrm{~h}$, repeating the process after $24 \mathrm{~h}$ and letting it rest for seven days.

Prior to the experiments, plant phytotoxicity to treatments was evaluated. Treatments in which plants showed anomalies in their development and plant coloration, with leaf browning on the leaves, were discarded.

In order to check the activity of essential oils, plants were inoculated in the petiole region 60 days after sowing with a bacterial suspension, adjusted in $A_{530}=0.36\left(1 \times 10^{9} \mathrm{UFC} \mathrm{mL} \mathrm{L}^{-1}\right)$ with a photocolorimeter, using the pricking method, adapted from Ren et al. (2001), in which plant tissue is penetrated with the help of hypodermal syringes, and the bacterial suspension is injected into the foliar mesophyll. Plants remained in a wet chamber for twelve hours, using moistened plastic bags around the plants under greenhouse conditions ( $\mathrm{T}$ of $25.2^{\circ} \mathrm{C} \pm 2$ and $\mathrm{RH}$ of $57 \% \pm 2$ ).

After 12 hours, lettuce plants were pulverized with all concentrations that had positive in vitro results, and that did not cause essential oil phytotoxicity. To obtain the oil concentrations applied directly onto the plant in the treatments, oils were emulsified with tween $20(1: 1)$ and diluted in SDW until the desired concentration was obtained. Evaluations were performed every six hours after inoculation until thirty hours were completed.

The following epidemiological components were analyzed: A) Incidence; B) Severity; C) Reduced Disease Incidence (RDI); D) Reduced Disease Severity (RDS); E) Area Under Disease Progress Curve (AUDPC).

Disease severity was estimated with the help of a descriptive scale ranging from 1 to 9 , adapted from Ren et al. (2001), where: $1=$ no lesion on the inoculated petiole, $2=$ less than $5 \mathrm{~mm}, 3=$ lesions between 5 and $10 \mathrm{~mm}$ in the inoculated petiole, $4=$ more than $10 \mathrm{~mm}$ in the inoculated petiole but not into the leaves, $5=$ lesions reached the leaf blade and main stem, $6=$ the main stem was infected but no symptoms in noninoculated leaves, 7= main stem, and other leaves also infected $8=$ whole plant nearly dead, and 9= plant dead.

Reduced Disease Incidence was estimated using the formula adapted and proposed by Silva et al. (2014) $\mathrm{RDI} \%=[($ INCT-INCTr) $/$ INCT $] \times 100$, where INCT = Incidence on the witness and INCTr = Incidence on the treatment. Likewise, Reduced Disease Severity was estimated using the formula RDS\% $=[($ SEVTSEVTr)/SEVT] x 100, where SEVT = Severity of witness, and SEVTr = Severity of treatment.

AUDPC was calculated using the formula proposed by Shaner and Finney (1977): $=\Sigma[(Y i+n 1+Y i) / 2]$ $[\mathrm{Xi}+\mathrm{I}-\mathrm{Xi}]-1=1$, where $\mathrm{Yi}$ is disease proportion in the ith repetition; $\mathrm{Ti}$ is time in hours in the ith observation, and $\mathrm{n}$ is the total number of observations. 
The oil with the best result in the in vivo experiment conducted in a greenhouse was evaluated for its curative and preventive effect.

\section{Determination of the minimum inhibitory concentration of sage oil}

Based on in vivo results obtained in the greenhouse, the experiment with sage oil was repeated and the concentration was decreased to find the lowest inhibitory concentration, in order to confirm the curative effects of the treatment with this oil and evaluate its preventive effect and determine an optimal concentration for recommended application. Therefore, the following concentrations were tested: $0.0 \%$, $0.15 \%, 0.25 \%, 0.50 \%$, and $0.75 \%$, using the curative and preventive treatment methodology.

The preventive method consisted of applying sage oil at different concentrations 72 hours prior to inoculation with the bacterial suspension $P$. aroidearum adjusted in $A_{530}=0,36\left(1 \times 10^{9} \mathrm{UFC} \mathrm{mL}^{-1}\right)$ with a photocolorimeter using the pricking method (Ren et al. 2001). The curative method followed the same methodology used during the study of the effects of all essential oils, in which the treatment at different concentrations was sprayed on lettuce plants 12 hours after inoculation. In order to obtain the essential oil concentrations, used both for bacterial suspension inoculation and to evaluate epidemiological components 'Incidence', 'Severity', and 'AUDPC', the methodologies used in the previous experiment were also adopted.

\section{Essential oil composition}

The identification of compounds essential oil compounds was performed by gas chromatography at the Instituto de Pesquisas em Fármacos e Medicamento (IPeFarM) of the Universidade Federal da Paraíba (UFPB), using a gas chromatograph coupled to a mass spectrophotometer, model GCMS-QP2010 Ultra, in Shimadzu equipment.

The chromatographic column used was capillary RTX-5MS (5\% Diphenyl / 95\% dimethyl polysiloxane), $30 \mathrm{~m}$ long and $0.25 \mathrm{~mm}$ internal diameter.

The compounds were identified by comparing the mass spectra with the spectra in the equipment database, NIST2008, NIST2008 + Shimadzu, and FFNSC 1.3.

\section{Statistical analyses}

The in vitro experiment was conducted with an Entirely Randomized Design, with five replicates in each treatment, each replicate represented by one Petri dish. The in vivo experiments were comprised of four replicates, with each replicate comprised of four leaves in a Completely Randomized Design. Each experiment was repeated twice. Data obtained were analyzed and submitted to a test of comparison of means or a polynomial regression test with the help of the R (version 3.5.1) (R Development Core Team) and Sisvar (version 5.6) programs.

\section{Results and Discussion}

The pathogenicity test was successfully performed as soft rot symptoms were reduced in the hosts tested, showing the pathogenicity of isolate UNEB 3.

The antimicrobial activity of essential oils derived from the species studied was initially determined based on the in vitro sensitivity of the bacterial isolate Pectobacterium aroidearum (UNEB 3). Compared to the witness, palmarosa, sage, citronella, lemongrass, and clove oils were observed to have positive results of inhibition of bacterial colony growth at a concentration of $0.25 \%$. Sage oil, on the other hand, inhibited bacterial growth at a concentration of $0.75 \%$. Essential orange, rosemary, bergamot, ginger, and melaleuca oils were not active in the concentration range studied (Table 1).

In the greenhouse assay, which was conducted to determine whether the most effective concentrations of essential oils in in vitro tests also had phytotoxicity in lettuce, clove, and orange oils (1.0\%), palmarosa and citronella oils ( 0.75 and $1.0 \%)$, and lemongrass oil (0.75 and $1.0 \%)$ were observed to be phytotoxic.

Lettuce plants in which the preventive treatment was applied with sage oil at 0.50 and $0.75 \%$ had highly effective control with a $100 \%$ reduction in disease incidence and severity. These data are confirmed 
as these plants also had the lowest AUDPC. Sage oil at $0.25 \%$ and $1.0 \%$ also had satisfactory results with $93.75 \%$ and $81.25 \%$ of reduced disease incidence, respectively (Table 2 ).

Table 1. In vitro sensitivity of Pectobacterium aroidearum to essential oils, determined by counting colonies in CPG culture medium.

\begin{tabular}{cccccc}
\hline \multirow{2}{*}{ Essential oil } & \multicolumn{5}{c}{ Concentration } \\
\cline { 2 - 6 } & $0 \%$ & $0.25 \%$ & $0.5 \%$ & $0.75 \%$ & $1.0 \%$ \\
\hline Orange & $8.35^{\mathrm{aA}}$ & $8.33^{\mathrm{a} a \mathrm{~A}}$ & $8.21^{\mathrm{aA}}$ & $8.11^{\mathrm{aA}}$ & $8.16^{\mathrm{aA}}$ \\
Rosemary & $8.09^{\mathrm{aA}}$ & $8.70^{\mathrm{aA}}$ & $8.37^{\mathrm{aA}}$ & $8.08^{\mathrm{aA}}$ & $3.98^{\mathrm{bB}}$ \\
Palmarosa & $8.40^{\mathrm{aA}}$ & $0.00^{\mathrm{bB}}$ & $0.00^{\mathrm{cB}}$ & $0.00^{\mathrm{bB}}$ & $0.00^{\mathrm{cB}}$ \\
Sage & $8.05^{\mathrm{aA}}$ & $1.86^{\mathrm{bBC}}$ & $3.61^{\mathrm{bB}}$ & $0.00^{\mathrm{bC}}$ & $0.00^{\mathrm{cC}}$ \\
Bergamot & $8.38^{\mathrm{aA}}$ & $8.23^{\mathrm{aA}}$ & $7.97^{\mathrm{aA}}$ & $8.00^{\mathrm{aA}}$ & $7.90^{\mathrm{aA}}$ \\
Ginger & $8.45^{\mathrm{aA}}$ & $8.18^{\mathrm{aA}}$ & $8.33^{\mathrm{aA}}$ & $8.21^{\mathrm{aA}}$ & $4.05^{\mathrm{bB}}$ \\
Citronella & $8.33^{\mathrm{aA}}$ & $0.00^{\mathrm{bB}}$ & $0.00^{\mathrm{cB}}$ & $0.00^{\mathrm{bB}}$ & $0.00^{\mathrm{cB}}$ \\
Lemongrass & $8.41^{\mathrm{aA}}$ & $0.00^{\mathrm{bB}}$ & $0.00^{\mathrm{cB}}$ & $0.00^{\mathrm{bB}}$ & $0.00^{\mathrm{cB}}$ \\
Clove & $8.46^{\mathrm{aA}}$ & $0.00^{\mathrm{bB}}$ & $0.00^{\mathrm{cB}}$ & $0.00^{\mathrm{bB}}$ & $0.00^{\mathrm{cB}}$ \\
Melaleuca & $8.54^{\mathrm{aA}}$ & $8.25^{\mathrm{aA}}$ & $8.17^{\mathrm{aA}}$ & $7.90^{\mathrm{aA}}$ & $7.83^{\mathrm{aA}}$ \\
\hline
\end{tabular}

${ }^{1}$ Means followed by the same lowercase letter in the column and uppercase letter on the row do not differ statistically using Tukey's test with $(\mathrm{P} \leq 0.05) .{ }^{2}$ Values expressed in Log (UFC $\left.\mathrm{mL}^{-1}+1\right)$.

Table 2. Curative effect of essential oils in the management of soft rot in lettuce caused by Pectobacterium aroidearum evaluated by the epidemiological components Incidence (INC), Reduced Disease Incidence compared to the witness (RDI), Severity (SEV), Reduced Disease Severity compared to the witness (RDS), Incubation Period (IP), and Area Under Disease Progress Curve (AUDPC).

\begin{tabular}{ccccccc}
\hline Treatments & INC (\%) & RDI (\%) & SEV & RDS (\%) & PI (hours) & AUDPC \\
\hline Sage 0.25\% & $6.25^{\mathrm{a}^{1}}$ & $93.75^{\mathrm{ab}}$ & $1.125^{\mathrm{a}^{2}}$ & $74.18^{\mathrm{ab}}$ & $0.375^{\mathrm{a}}$ & $26.437^{\mathrm{ab}}$ \\
Sage 0.50\% & $0^{\mathrm{a}}$ & $100^{\mathrm{a}}$ & $1.0^{\mathrm{a}}$ & $100^{\mathrm{a}}$ & $0^{\mathrm{a}}$ & $24.0^{\mathrm{a}}$ \\
Sage 0.75\% & $0^{\mathrm{a}}$ & $100^{\mathrm{a}}$ & $1.0^{\mathrm{a}}$ & $100^{\mathrm{a}}$ & $0^{\mathrm{a}}$ & $24.0^{\mathrm{a}}$ \\
Sage 1.0\% & $18.75^{\mathrm{ab}}$ & $81.25^{\mathrm{abc}}$ & $1.375^{\mathrm{ab}}$ & $68.62^{\mathrm{abc}}$ & $3.375^{\mathrm{ab}}$ & $30.0^{\mathrm{ab}}$ \\
Lemongrass 0.25\% & $50^{\mathrm{ab}}$ & $50^{\mathrm{bcd}}$ & $2.5625^{\mathrm{ab}}$ & $43.62^{\mathrm{bc}}$ & $7.125^{\mathrm{ab}}$ & $47.43^{\mathrm{abc}}$ \\
Clove 0.25\% & $37.5^{\mathrm{ab}}$ & $62.5^{\mathrm{abcd}}$ & $2.187^{\mathrm{ab}}$ & $52.75^{\mathrm{abc}}$ & $5.25^{\mathrm{ab}}$ & $42.93^{\mathrm{abc}}$ \\
Clove 0.50\% & $25^{\mathrm{ab}}$ & $75.0^{\mathrm{abcd}}$ & $1.812^{\mathrm{ab}}$ & $60.37^{\mathrm{abc}}$ & $3.0^{\mathrm{ab}}$ & $38.05^{\mathrm{abc}}$ \\
Clove 0.75\% & $56.25^{\mathrm{ab}}$ & $43.75^{\mathrm{cd}}$ & $3.375^{\mathrm{b}}$ & $41.56^{\mathrm{c}}$ & $6.375^{\mathrm{ab}}$ & $62.62^{\mathrm{abc}}$ \\
Palmarosa 0.25\% & $31.25^{\mathrm{ab}}$ & $68.75^{\mathrm{abcd}}$ & $1.8125^{\mathrm{ab}}$ & $58.81^{\mathrm{abc}}$ & $3.0^{\mathrm{ab}}$ & $41.06^{\mathrm{abc}}$ \\
Palmarosa 0.50\% & $50^{\mathrm{ab}}$ & $50^{\mathrm{bcd}}$ & $2.562^{\mathrm{ab}}$ & $45.12^{\mathrm{bc}}$ & $6.0^{\mathrm{ab}}$ & $49.87^{\mathrm{abc}}$ \\
Citronella 0.25\% & $68.75^{\mathrm{ab}}$ & $31.25^{\mathrm{d}}$ & $2.875^{\mathrm{ab}}$ & $35.81^{\mathrm{c}}$ & $6.375^{\mathrm{ab}}$ & $62.62^{\mathrm{bc}}$ \\
Witness & $100^{\mathrm{b}}$ & $\mathrm{NA}^{4}$ & $4.437^{\mathrm{b}}$ & NA & $11.25^{\mathrm{b}}$ & $77.81^{\mathrm{c}}$ \\
CV (\%) & 58.45 & 54.86 & 25.35 & 35.08 & 42.66 & 17.40 \\
\hline
\end{tabular}

${ }^{1}$ Means followed by the same lowercase letter do not differ statistically using Tukey's test with $5 \%$ significance. ${ }^{2}$ Incidence (INC), expressed by the percentage of sick plants for each corresponding concentration. ${ }^{3}$ Data were transformed $(\sqrt{x+0.5})$ in order to better adjust to the analysis of variance (ANOVA). ${ }^{4}$ Not applicable.

Other treatments also had satisfactory results, as they did not statistically differ from sage oil, which had the best indices in the analyses of epidemiological variables. Clove oil ( 0.25 and $0.50 \%)$ and palmarosa oil $(0.25 \%)$ are some examples, as they significantly reduced disease incidence and severity.

Literature on the effect of essential plant oils on P. aroideraum is scarce. However, Joshi et al. (2016), using eugenol, a major constituent of clove oil, observed reduced production of $P$. aroidearum and $P$. carotovorum subsp. brasiliense biofilm in cabbage (Brassica oleracea L.), potato (Solanum tuberosum L.), and calla lily (Zantedeschia aethiopica (L.) Spreng.). The biofilm produced by these bacteria is a kind of aggregate that allows them to fixate onto host tissue (Kubheka et al. 2013). In the same study, the reduced enzymatic activity of pectate lyase, polygalacturonase, and protease was observed. These enzymes are responsible for macerating host tissue, causing the typical symptom of soft rot. 
Jeong et al. (2009) observed that lemongrass oil inhibited the in vitro growth of 3 different $P$. carotovorum isolates at $0.50 \%$. The authors indicated that this inhibition is due to the physical nature of essential oils, which are capable of penetrating the tissue 100 times as fast as water, and 10,000 times as fast as salts since they have a low molecular weight (Burt et al. 2005; Edris 2007). The antimicrobial properties of lemongrass essential oil might be attributed to the presence of $80 \%$ of citral, citronella, geraniol, methyl-heptane, n-dectil-aldehyde, and linalool in plants, which are active ingredients used to produce pesticides (Oparaeke 2004; Simeon and Abubakar 2014).

As citronella oil derives from the same genus as lemongrass, it has similar characteristics regarding its antimicrobial activity. Costa et al. (2008) observed that citronella oil was more effective than the antibiotic tetracycline in inhibiting the growth of six P. carotovorum subsp. carotovorum (Jones 1901) Hauben et al. 1998 isolates at a MIC of $1 \%$. Positive results are also found in other species of plant disease-causing bacteria, such as Pseudomonas syringae pv. tomato (Okabe) Young, Dye \& Wilkie (Silva et al. 2014), Ralstonia solanacearum (E.F. Smith) Yabuuchi et al. (Martins et al. $201 \quad 0$ 0), Agrobacterium tumefaciens (Smith and Townsend 1907) Conn 1942, and Streptomyces spp. Waksman \& Henrici 1943 (Huang and Laksman 2010).

In the analysis of data from the in vivo experiment with sage oil, linear regression, and polynomial regression were adjusted to the treatment for the variables analyzed, and satisfactory coefficients of determination $\left(R^{2}\right)$ were obtained, except for severity in the preventive control (Figure 1 ). In order to determine the lowest oil concentration with which the lowest incidence, severity, and AUDPC were obtained, the first derivative in the regressions equation with the highest adjustment obtained was equal to zero.

In the preventive treatment, a small reduction in disease incidence was observed using sage essential oil, with values close to $40 \%$ at the highest concentration studied compared to the witness (Figure $1 \mathrm{~A}$ ). Regarding the epidemiological variable 'severity', sage oil was not capable of reducing the severity of soft rot in lettuce and did not significantly differ from the witness (Figure 1B).

Some of these studies show that the use of essential oils might be considered a viable alternative in the preventive treatment of plant diseases, mostly those of fungal nature, such as tomato bacterial spot (Alternaria solani) (Lucas et al. 2012) and anthracnose in sorghum (Colletotrichum graminicola) (SarmentoBrum et al. 2013), with better effects than the curative treatment. Lucas et al. (2012), in one of the few studies on the preventive oil-based treatment of pathogenic bacteria, obtained reduced bacterial spot in tomato caused by Xanthomonas vesicatoria, by treating the plants with clove essential oil. However, in our study, sage oil did not show efficacy in the preventive control of soft rot in lettuce.

When applying the curative treatment, disease incidence reduced by approximately $90 \%$ starting at a concentration of $0.25 \%$ of sage oil, and it decreased with increased concentration (Figure $1 \mathrm{E}$ ). The lowest disease incidence value was obtained at $0.5 \%$.

For the epidemiological variable 'severity', plants had the lowest severity score at a concentration of approximately $0.79 \%$ according to the scale proposed by Ren et al. (2001), with values of approximately 1.62. The lowest AUDPC value was obtained at 0.5741 of oil concentration, with which values of approximately 31.6 were obtained (Figure 1F). Therefore, considering concentrations that caused the highest reduction in all epidemiological variables studied, the mean concentration of $0.64 \%$ caused reduced incidence, severity, and AUDPC.

The results obtained in this study are positive compared to the literature. In one of the few studies found using sage oil to treat bacteria of the genus Pectobacterium, Silva et al. (2012) obtained severity values of 4.7 with sage oil at $0.5 \%$ in a $P$. carotovorum subsp. carotovorum isolate and did not have positive in vitro results.

Sage essential oil is also reported to have positive effects on Gram-negative bacteria, including Pectobacterium atrosepticum (Van Hall 1902) Gardan et al. 2003, reducing the effects of this disease by up to $65 \%$ (Zaidi-Yahiaoui et al. 2009). There is more information on the effects of sage in the reduction of diseases in pathogenic fungi, such as grapevine mildew caused by the fungus Plasmopara vitícola (Berk. and M.A. Curt.) Berl. \& De Toni. In a study conducted by Dagostin et al. (2010), an extract derived from sage provided a $94 \%$ reduction in disease incidence and a $63 \%$ reduction in AUDPC for disease severity in berries and leaves, reaching a disease control level similar to that obtained with the traditional chemical control with. copper. 

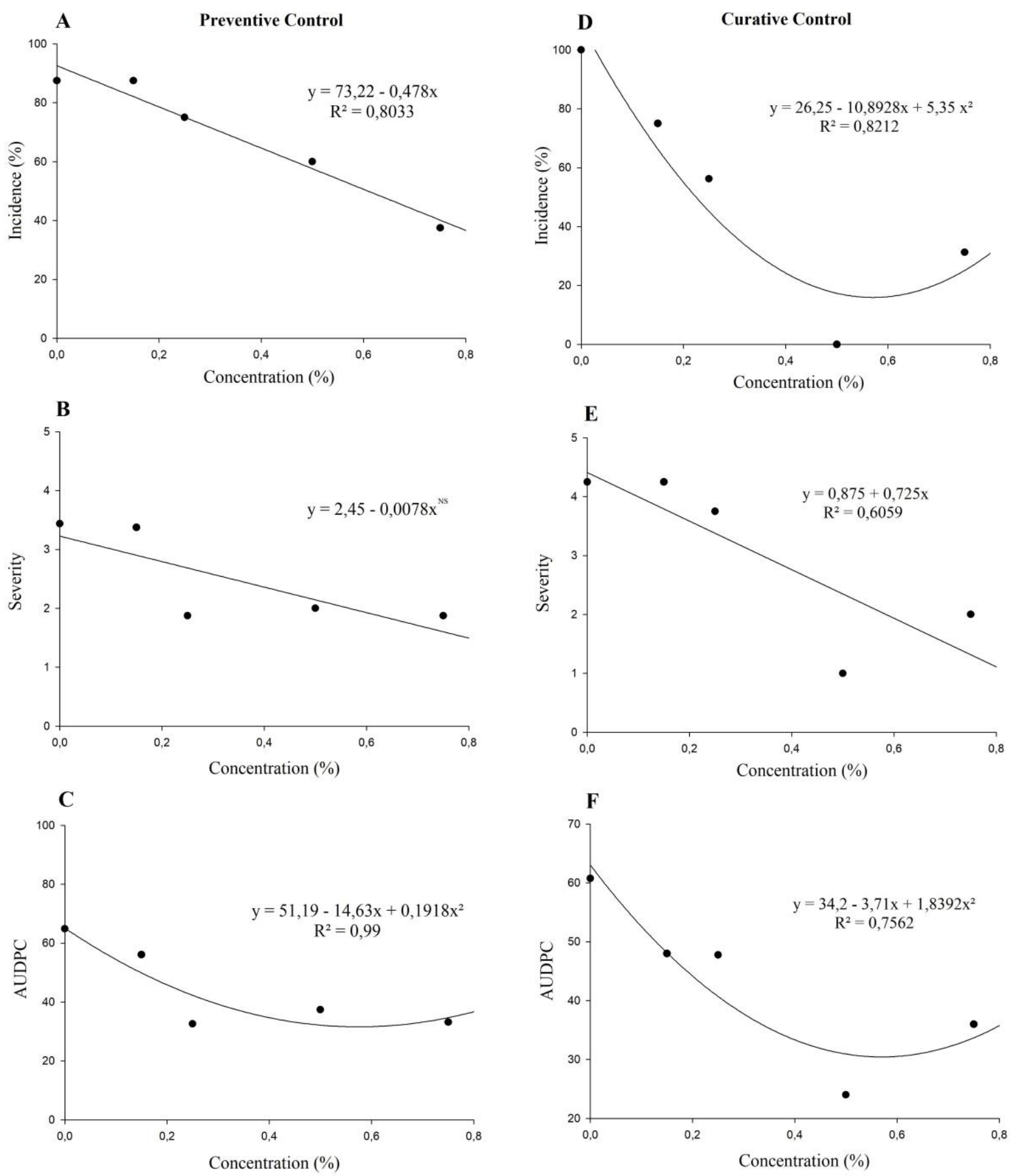

Figure 1. Effect of sage essential oil in the preventive and curative treatment of soft rot in lettuce caused by $P$. aroidearum. A - disease incidence in preventive control; B - disease severity in preventive control; C area Under Disease Progress Curve (AUDPC) in prevetive control; D - disease incidence in curative control; $\mathrm{E}$ - disease severity in curative control; F - area Under Disease Progress Curve (AUDPC) in curative control.

These results might be explained by Pop et al. (2016) who observed that the antioxidant activity of sage decreases the concentration of the stable DPPH (2,2-diphenyl-1-picrylhydrazyl) free radical, reducing its concentration by up to $92 \%$. DPPH is frequently used to evaluate the antioxidant activity of natural compounds in an easy, rapid, and sensitive manner (Al-Qudah et al. 2014).

Kuzma et al. (2007), who evaluated the antimicrobial activity of sage, initially observed the presence of diterpenoids in its composition, derived from its secondary metabolism. These diterpenoids have a bacteriostatic behavior in Gram-positive and Gram-negative bacteria, as well as in fungi. Aside from the bacteriostatic effect, these compounds showed to be bactericidal for Gram-positive bacteria. According to the authors, diterpenoids prevent bacterial adhesion and biofilm formation. Some studies also show that several species of the genus Salvia have antibacterial effects, e.g., the study by Hussain et al. (2011), in which the major compounds of Salvia officinalis, linalyl acetate, and linalool, had the highest activity. 


\section{Essential oil composition}

In total, 74 constituents of sage essential oil were found, of which 70 could be identified. Of these, the compounds present in Table 3 presented the highest concentrations. Linalyl acetate, 9-octadecenoic acid (9-Octadecenoic acid), and linalool were the major compounds because they had the highest relative concentration rates, with $23.25,9.84$, and $9.33 \%$ of the total constituents, respectively.

Table 3. Relative concentration (\%), obtained by gas chromatography, of the sage essential oil constituents.

\begin{tabular}{cc}
\hline Essential oils constituents & Relative concentration (\%) \\
\hline Linalyl acetate & 23.25 \\
9-Octadecenoic acid, (E) & 9.84 \\
Linalool & 9.33 \\
9,12-Octadecadiecoic acid (Z, Z) & 6.85 \\
Bicyclo [3.1.0] hexan-3-one, 4-methyl-1-(1-methylethyl) & 6.00 \\
Camphor & 4.86 \\
Octadecanoic acid & 4.31 \\
6,11-Hexadecadien-1-ol & 4.28 \\
Eucalyptol (1,8-CINEOLE) & 2.69 \\
n-Hexadecanoic acid & 2.35 \\
Others & 26.24 \\
\hline
\end{tabular}

Some research has already been conducted with these major compounds, highlighting linalool as a starting compound for several important syntheses, such as linalyl acetate itself, which was found in higher concentration. In addition, it has been tested as acaricide, bactericide, and fungicide and is present in other oils, such as bergamot (Aguiar et al. 2017).

Despite reports of the efficiency of these constituents, little research is focused on the use of these components for the development of products aimed at controlling phytopathogenic bacteria. Although there are no studies in this context, due to the efficiency of sage oil in reducing soft rot in the present work, there is a clear need for studies of these components alone or in combination, and not just the major components, for the control of $P$. aroidearum.

Thus, knowing the constitution of this essential oil becomes essential, since it will be possible to direct studies that aim to take advantage of its potentialities and modes of action in bacteria that cause disease in plants.

\section{Conclusions}

In the present study, the preventive treatment was not efficient for the management of soft rot in lettuce, however, that sage oil at the concentration $0.64 \%$ was capable to reduce the bacterial growth of $P$. aroidearum when applied for curative purposes and can be recommended for the control of this disease. The linalyl acetate and linalool, found in higher concentrations in the chromatographic analysis, probably conferred the bactericidal capacity of the essential oil of sage, being potential for use in the control of $P$. aroidearum in lettuce disease.

\footnotetext{
Authors' Contributions: BARROSO, K.A.: conception and design, acquisition of data, analysis and interpretation of data, drafting the article, critical review of important intellectual content; OLIVEIRA, X.B.: conception and design, acquisition of data, analysis and interpretation of data; QUEIROZ, M.F.: conception and design, acquisition of data, analysis and interpretation of data; ALMEIDA, C.O.: conception and design, acquisition of data; LORENZO, V.P.: acquisition of data, analysis and interpretation of data; VILAR, F.C.R.: acquisition of data, analysis and interpretation of data; PAZ, C.D.: critical review of important intellectual content; PEIXOTO, A.R.: conception and design, acquisition of data, analysis and interpretation of data, drafting the article, critical review of important intellectual content. All authors have read and approved the final version of the manuscript.
}

Conflicts of Interest: The authors declare no conflicts of interest.

Ethics Approval: Not applicable. 
Acknowledgments: The authors would like to thank the funding for the realization of this study provided by the Brazilian agency CAPES (Coordenação de Aperfeiçoamento de Pessoal de Nível Superior - Brasil), Finance Code 1602525.

\section{References}

AGUIAR, E.M.M.M., et al. Hidrolato de Pau Rosa (Aniba rosaeodora duckei Kostermans) como insumo para cosméticos. Scientia Amazonia. 2017, 6(1), 94-106.

AL-QUDAH, M.A., et al. Flavonoid and phenolic compounds from Salvia palaestina L. growing wild in Jordan and their antioxidant activities. Phytochemistry. 2014, 99(1), 115-120. https://doi.org/10.1016/i.phytochem.2014.01.001

BARROSO, K.A., et al. First report of Pectobacterium aroidearum causing soft rot in lettuce and Chinese cabbage in Brazil. Plant Disease. 2019, 103(12), 3274. https://doi.org/10.1094/PDIS-12-18-2237-PDN

BERIAM, L.O.S. Doenças bacterianas em hortaliças. Biológico. 2007, 69(2), 81-84.

BURT, S.A., et al. Increase in activity of essential oil components carvacrol and thymol against Escherichia coli O157:H7 by addition of food stabilizers. Journal of food protection. 2005, 68(5), 919-926. https://doi.org/10.4315/0362-028X-68.5.919

CONN, H.J. Validity of the genus Alcaligenes. Journal of Bacteriology. 1942, 44, 353-360.

CONNER, D.E., 1993. Naturally occurring compounds. In: DAVIDSON, P. and BRANEN, A.L. (eds.). Antimicrobials in foods. New York: Marcel Dekker, pp. 441-68.

COSTA, C.M.G.R., et al. Óleo essencial de citronela no controle da bactéria fitopatogênica Erwinia carotovora. Tecnologia \& Ciência Agropecuária. 2008, 2(12), 11-14.

DAGOSTIN, S., et al. Salvia officinalis extract can protect grapevine against Plasmopara viticola. Plant Disease. 2010, 94(5), 575-580. https://doi.org/10.1094/PDIS-94-5-0575

EDRIS, A.E. Pharmaceutical and therapeutic potentials o essential oils and their individual volatile constituents: a review. Phytotherapy Research. 2007, 21(4), 308-323. https://doi.org/10.1002/ptr.2072

GARDAN, L., et al. Elevation of three subspecies of Pectobacterium carotovorum to species level: Pectobacterium atrosepticum sp. nov., Pectobacterium betavasculorum sp. nov. and Pectobacterium wasabiae sp. nov. International Journal of Systematic and Evolutionary Microbiology. 2003, 53(2), 381-391. https://doi.org/10.1099/ijs.0.02423-0

HAUBEN, L., et al. Phylogenetic position of phytopathogens within the Enterobacteriaceae. Systematic and Applied Microbiology. 1998, 21(3), 384-397. https://doi.org/10.1016/S0723-2020(98)80048-9

HUANG, Q. and LAKSMAN, D.K. Effect of clove oil on plant pathogenic bacteria and bacterial wilt of tomato and geranium. Journal of Plant Pathology. 2010, 92(3), 701-707. https://doi.org/10.4454/JPP.V9213.316

HUSSAIN, A.I., et al. Composition, antioxidant, and chemotherapeutic properties of the essential oils from two Origanum species growing in Pakistan. Revista Brasileira de Farmacognosia. 2011, 21(6), 943-952. https://doi.org/10.1590/S0102-695X2011005000165

JEONG, M.R., et al. Essential oil prepared from Cymbopogon citrates exerted an antimicrobial activity against plant pathogenic and medical microorganisms. Mycobiology. 2009, 37(1), 48-52. https://doi.org/10.4489/MYCO.2009.37.1.048

JONES, L.R. A soft rot of carrot and other vegetable caused by Bacillus carotororus. Victoria Agric. Exp. Station Ann. Rep. 1901, 13, $299-332$.

JOSHI, J.J., et al. Plant phenolic acids affect the virulence of Pectobacterium aroidearum and P. carotovorum ssp. brasiliense via quorum sensing regulation. Molecular plant pathology. 2016, 17(4), 487-500. https://doi.org/10.1111/mpp.12295

KUBHEKA, G.C., et al. Colonization patterns of a mCherry-tagged Pectobacterium carotovorum subsp. brasiliense strain in potato plants. Phytopathology. 2013, 103(12), 1268-1279. https://doi.org/10.1094/PHYTO-02-13-0049-R

KUZMA, L., et al. Antimicrobial activity of diterpenoids from hairy roots of Salvia sclarea L.: Salvipisone as a potential anti-biofilm agent active against antibiotic-resistant Staphylococci. Phytomedicine. 2007, 14(1), 31-35. https://doi.org/10.1016/i.phymed.2005.10.008

LUCAS, G.C., et al. Antibacterial activity of essential oils on Xanthomonas vesicatoria and control of bacterial spot in tomato. Pesquisa Agropecuária Brasileira, 2012, 47(3), 351-359. https://doi.org/10.1590/S0100-204X2012000300006

MARIANO, R.L.R. and SOUZA, E.B. Manual de práticas em fitobacteriologia. 3rd ed. Recife: Universidade Federal Rural de Pernambuco, 2016.

MARTINS, E.S.C.S., et al. Atividade antibacteriana de óleos essenciais de citronela, alecrim e erva-cidreira no controle in vitro da bactéria Ralstonia solanacearum em tomateiro. Tecnologia \& Ciência Agropecuária. 2010, 3(3), 29-34.

MICHEREFF, S.J., et al. Ecologia e manejo de patógenos radiculares em solos tropicais. 1st ed. Recife: UFRPE, Imprensa Universitária, 2005.

MILITELLO, M., et al. Chemical composition, and antibacterial potential of Artemisia arborescens L. essential oil. Current Microbiology. 2011, 62(4), 1274-1281. https://doi.org/10.1007/s00284-010-9855-3

NABHAN, S., et al. Pectobacterium aroidearum sp. nov., a soft rot pathogen with preference for monocotyledonous plants. International Journal of Systematic and Evolutionary Microbiology. 2013, 63(7), 2520-2525. https://doi.org/10.1099/ijs.0.046011-0 
OPARAEKE, A.M. Collection, Identification and screening of indigenous herbal extracts and waste matter for control of insect pests of cowpea (Vigna unguiculata L.) Walp. Zaria, Nigeria: Ahmadu Bello University, 2004.

PARET, M.L., et al. Effect of plant essential oils on Ralstonia solanacearum race 4 and bacterial wilt of edible ginger. Plant Disease. 2010, 94(5), 521-527. https://doi.org/10.1094/PDIS-94-5-0521

POP, A.V., et al. Determination of Antioxidant Capacity and Antimicrobial Activity of Selected Salvia Species. Bulletin UASVM Food Science and Technology. 2016, 73(1), 14-18. http://dx.doi.org/10.15835/buasvmen-fst:11965

RAID, R.N., 1997. Soft rot of lettuce. In: DAVIS, R.M., SUBBARAO, K.V., RAID, R.N. and KURTZ, E.A. (eds.). Compendium of lettuce diseases. St. Paul: APS Press, pp. 30-31.

REN, J., PETZOLDT, R. and DICKSON, M.H. Genetics, and population improvement resistance to bacterial soft rot Chinese cabbage. Euphytica. 2001, 117(3), 197-207. https://doi.org/10.1023/A:1026541724001

SALA, F.C. and COSTA, C.P.D. Retrospectiva e tendência da alfacicultura brasileira. Horticultura Brasileira. 2012, 30(2), $187-194$. https://doi.org/10.1590/S0102-05362012000200002

SARMENTO-BRUM, R.B.C., et al. Efeito de óleos essenciais de plantas medicinais sobre a antracnose do sorgo. Bioscience Journal. 2013, 29(5), 1549-1557.

SEDIYAMA, M.A.N., et al. Uso de fertilizantes orgânicos no cultivo de alface americana (Lactuca sativa L.) 'Kaiser'. Revista Brasileira de Agropecuária Sustentável. 2016, 6(2), 66-74. http://dx.doi.org/10.21206/rbas.v6i2.308

SHANER, G. and FINNEY, R.E. The effect of nitrogen fertilization on the expression of slow-mildewing resistance in Knox wheat. Phytopathology. 1977, 67(8), 1051-1056. http://doi.org/10.1094/Phyto-67-1051

SILVA, C.L., et al. Óleos essenciais e extratos vegetais no controle da podridão mole em alface crespa. Horticultura Brasileira. 2012, 30(4), 632638. https://doi.org/10.1590/S0102-05362012000400012

SILVA, O.E., MARTINS, S.J. and ALVES, E. Essential oils for the control of bacterial speck in tomato crop. African Journal of Agricultural Research. 2014, 9(34), 2624-2629. https://doi.org/10.5897/AJAR2014.8918

SILVEIRA, S.M.D., et al. Composição química e atividade antibacteriana dos óleos essenciais de Cymbopogon winterianus (citronela), Eucalyptus paniculata (eucalipto) e Lavandula angustifolia (lavanda). Revista do Instituto Adolfo Lutz. 2012, 71(3), 462-470.

SIMEON, A.U. and ABUBAKAR, A. Evaluation of some plant extracts for the control of bacterial soft rot of tubers. Journal of Experimental Agriculture International. 2014, 4(12), 1869-1876. https://doi.org/10.9734/AJEA/2014/12309

SMITH, E.F. and TOWNSEND, C.O. A plant-tumor of bacterial origin. Science. 1907, 25, 671-673.

VAN HALL, C.J.J. Bijdragen tot de Kennis der Bakteriele Plantenziekten. Zeitschrift Für Pflanzenkrankheiten. 1903, 13(2), $116-118$. https://www.jstor.org/stable/43219527

VIUDA-MARTOS, M., et al. Chemical composition, and antioxidant and anti-Listeria activities of essential oils obtained from some Egyptian plants. Journal of Agricultural and Food Chemistry. 2010, 58(16), 9063-9070. https://doi.org/10.1021/jf101620c

ZAIDI-YAHIAOUI, R., et al. Potential of Olea europeae leaves and cake and Salvia officinalis for controlling soft rot potato tubers. 1st ed. Alfortville: Association Française de Protection des Plantes (AFPP), 2009.

Received: 26 April 2020 | Accepted: 4 April 2021 | Published: 29 December 2021

This is an Open Access article distributed under the terms of the Creative Commons Attribution License, which permits unrestricted use, distribution, and reproduction in any medium, provided the original work is properly cited. 